\title{
Distribution and Virulence Gene Comparison of Aeromonas Strains Isolated from Diseased Fish and Water Environment
}

\author{
QUN LAN ZHOU ${ }^{1}$, YI JUAN WANG ${ }^{2}$, JUN XIE ${ }^{1 \star}$, XIAN PING GE ${ }^{1}$, BING WEN XI $^{1}$ and BO LIU ${ }^{1}$ \\ ${ }^{1}$ Freshwater Fisheries Research Center, Chinese Academy of Fishery Sciences, Key Open Lab for Genetic Breeding \\ of Aquatic Animals and Aquaculture Biology, Ministry of Agriculture, Wuxi City, Jiangsu, China \\ ${ }^{2}$ Jiangyan Fisheries Technical Guidance Station, Jiangyan, Jiangsu 225500, China
}

Submitted 28 December 2012, revised 18 April 2013, accepted 15 July 2013

Abstract

A total of 71 Aeromonas strains were isolated in the south of Jiangsu Province China in order to analyze the difference of Aeromonas spp. distribution between diseased fish and water environment. The sequence of 16S rDNA and gyrB demonstrated that the 71 Aeromonas isolates could be divided into 4 species, including A. veronii (55), A. hydrophila (11), A. salmonicida (3) and A. media (2). A. veronii was the most common species isolated from fish and water environment. All Aeromonas isolates were screened for three putative virulence genes, aer, hly and alt. hly was the most common gene among three virulence genes.

Ke y words: Aeromonas, diseased fish, gyrB, $16 \mathrm{~S}$ rDNA, virulence gene, water environment

Species of Aeromonas are common inhabitants of aquatic environments and have been described in connection with fish and human diseases (Saavedra et al., 2004; Figueras, 2005). At present the genus comprises 19 species: A. hydrophila, A. bestiarum, A. salmonicida, A. caviae (synonym A.punctata), A. media, A.eucrenophila, A.sobria, A.veronii (synonyms are A.ichthiosmia and A.culicicola), A.jandaei, A. schubertii, A. trota (synonym A. enteropelogenes), A. allosaccharophila, A. encheleia, A. popoffii, A. simiae, A. molluscorum, A. bivalvium, A. aquariorum, and A. tecta, as well as two DNA homology groups without a species name, Aeromonas sp. HG11 (proposed to be the synonym of A. encheleia) and HG13 (Enteric group 501) (Demarta et al., 2008; Harf-Monteil et al., 2004; Martin-Carnahan and Joseph, 2005; Martinez-Murcia et al., 2008; Minana-Galbis et al., 2004; Minana-Galbis et al., 2007; Pidiyar et al., 2002; Saavedra et al., 2006).

Direct sequencing of the $16 \mathrm{~S} r D N A$ gene is generally accepted as a stable and specific marker for bacterial identification (Marchandin et al., 2003). Although $16 \mathrm{~S}$ rDNA gene sequencing has contributed notably to the elucidation of the phylogenetic interrelationships between Aeromonas species, the resolution of this molecular 'clock' has now been superseded by those of some protein-encoding housekeeping genes such as gyrB and $r p o D$ (Yanez et al., 2003; Soler et al., 2004;
Martin-Carnahan and Joseph, 2005; Saavedra et al., 2006). The gyrB gene that encodes the B subunit protein of DNA gyrase (topoisomerase type II) is a single copy gene and is essential for DNA replication. This gene has been extensively used for studying phylogenetic relationship with various bacterial genera and its comparison with DNA-DNA hybridization results (Kasai et al., 2000).

Aeromonas are native of aquatic environments, and are frequently found in foods, including meat, fish, vegetables, fresh and sea water (Castro-Escarpulli et al., 2003). Species, such as A. hydrophila, A. bestiarum, A. veronii biovar sobria and A. sobria, have been associated with infections in kinds of fish species (Kozinska, 2007). Some strains of motile and nonmotile Aeromonads are involved in different fish diseases, such as septicemia, ulcerative disease, and furunculosis (Aberoum and Jooyandeh, 2010; Cristi et al., 2007). The mechanism of pathogenesis is complex and unclear (Janda and Abbott, 2010; Parker and Shaw, 2011). All genes that encode for virulence associated factors that allow the pathogen to establish infection in the host are defined as virulence genes. Virulence of aeromonads is considered to be multifactorial including cytotonic heat-labile (alt), and cytotonic heat-stable enterotoxins (ast), cytotoxic heat-labile enterotoxin $(a c t)$, aerolysin (aer), flagella A and flagella B $(f l a)$,

\footnotetext{
* Corresponding author: J. Xie, Freshwater Fisheries Research Center, Chinese Academy of Fishery Sciences, No. 9 Shanshui Road
} East, Wuxi City, Jiangsu 214081, China; phone: 086-510-85556566; e-mail: xiej@ffrc.cn 
lipase (lip), elastase (ela), serine protease (ser), ADPribosyltransferase toxin (aexT), and DNases (exu) (Sha et al., 2002; Chacon et al., 2003; Sen and Rodgers, 2004; Nam and Joh, 2007; Vilches et al., 2008; Nawaz et al., 2010). It is not clear whether there is a different virulent subset of Aeromonas species isolated from the diseased fish and the environment.

At the present study, in order to know the distribution difference of the Aeromonas between diseased fish and water environment, samples were collected form the diseased fish and pond water in the south of Jiangsu Province, China. All strains were sequenced with 16S $r D N A$ and $g y r B$ gene to identify the species. Meanwhile three virulence genes, aer, hly and alt, were screened to compare the difference between host and environment.

Presumptive Aeromonas strains were isolated from host (diseased fish) and water environment in the south of Jiangsu Province China. The diseased fish showed heavy dark, hemorrhaging in the eye and mouth, in the vicinity of the opercula, around the vent and the base of the fins, and on the surface of the body. Some of them even showed abdominal swelling with lots of ascetic fluid. Bacteria isolated from niches of diseased fish, such as fish body, gill, liver, intestine, vent, ascetic fluid etc., grew on plates of Rimler-Shotts Medium. Pond water were coated on plates of Rimler-Shotts Medium too. The isolates were presumptively identified as Aeromonas species by Gram-staining, cytochrome oxidase, catalase and oxidative/fermentative acid production from glucose (Hugh and Leifson, 1953). The putative Aeromonas strains $(n=71,43$ from diseased fish and 28 from water) were used in further analysis. DNA was extracted by using the UNIQ-10 Column Bacterial Genomic DNA Isolation Kit (Sangon Biotech (Shanghai) Co., Ltd, China). Strains were identified by the sequence of $16 \mathrm{~S} r D N A$ and $g y r B$. Primers $16 \mathrm{~S}$ $r D N A$ and $g y r B$ were in table I. Results were compared in a BLAST homology search with Aeromonas gene sequences deposited in the GenBank database.

All Aeromonas isolates could be divided into 4 species (table II), including A. veronii (55), A. hydrophila (11), A. salmonicida (3) and A. media (2). There were 43 strains isolated from the diseased fish, among which 30 were $A$. veronii, 10 were $A$. hydrophila and 3 were A. salmonicida. 28 strains were isolated from water environment, including A. veronii (25), A. hydrophila (1) and A. media (2). A. veronii was the most popular species whether Aeromonas strains were isolated from diseased fish (30) or from water (25). This was in agreement with previous studies (Figueras 2005; Ottaviani et al., 2011; Wuming Yang, 2010; Hu et al., 2012).

However, in a total of 11 A. hydrophila strains 10 were isolated from diseased fish and only 1 was from water environment. To compare the appearance ratio of Aeromonas species between the diseased fish and pond water using SPSS 11.0 Nonparametric Tests, it

Table I

Primers and annealing temperatures of $16 \mathrm{~S} r D N A, g y r B$ and virulence genes

\begin{tabular}{|l|l|c|}
\hline \multicolumn{1}{|c|}{ Genes } & \multicolumn{1}{|c|}{ Primers } & Tm $\left({ }^{\circ} \mathrm{C}\right)$ \\
\hline 16S rDNA & F: 5'-CAC GGA TCC AGA GTT TGA T(C/T) (A/C) TGG CTC AG-3' \\
& R: 5'-GTG AAG CTTACG G (C/T)T ACC TTG TTA CGA CTT-3' & 52 \\
\hline gyrB & $\begin{array}{l}\text { F: 5'-TCC GGC GGT CTG CAC GGC GT-3' } \\
\text { R: 5'-TTG TCC GGG TTG TAC TCG TC-3' }\end{array}$ & 59 \\
\hline aer & $\begin{array}{l}\text { F: 5'-GCTGAACCCATCTATCCTG-3' } \\
\text { R: 5'-TTTCTCCGGTAACAGGATTG-3' }\end{array}$ & 50 \\
\hline hly & $\begin{array}{l}\text { F: 5'-GGCCGGTGGCCCGAAGATACGGG-3' } \\
\text { R: 5'-GGCGGCGCCGGACGAGACGGG-3' }\end{array}$ & 65 \\
\hline Alt & $\begin{array}{l}\text { F: 5'-TGACCCAGTCCTGGCACGGC-3' } \\
\text { R: 5'-GGTGATCGATCACCACCAGC-3' }\end{array}$ & 60 \\
\hline
\end{tabular}

Table II

Aeromonas isolates obtained from diseased fish and water environment (\%)

\begin{tabular}{|l|c|c|c|c|c|c|c|}
\hline \multicolumn{1}{|c|}{ Diseased fish } & $\begin{array}{c}\text { Crucian } \\
\text { Carp }\end{array}$ & $\begin{array}{c}\text { Black } \\
\text { Carp }\end{array}$ & $\begin{array}{c}\text { Grass } \\
\text { Carp }\end{array}$ & Subtotal & $\begin{array}{c}\text { Water } \\
\text { Environment }\end{array}$ & $\begin{array}{c}\text { Bluntnose } \\
\text { Black Bream }\end{array}$ & Total \\
\hline Aeromonas veronii & 7 & 8 & 2 & 13 & 30 & 25 & 55 \\
\hline Aeromonas hydrophila & 1 & $/$ & 5 & 4 & 10 & 1 & 11 \\
\hline Aeromonas salmonicida & $/$ & $/$ & 3 & 0 & 3 & $/$ & 3 \\
\hline Aeromonas media & $/$ & $/$ & $/$ & $/$ & $/$ & 2 & 2 \\
\hline Subtotal & 8 & 8 & 10 & 17 & 43 & 28 & 71 \\
\hline
\end{tabular}


Table III

Virulence genes positive ratio of A. veronii and A. hydrophila isolated from the diseased fish and water environment (\%)

\begin{tabular}{|c|l|c|c|c|}
\hline Species & Isolated from & aer & hly & alt \\
\hline \multirow{2}{*}{ A. veronii } & Diseased fish & $23(7 / 30)$ & $41(12 / 30)$ & $33(10 / 30)$ \\
\cline { 2 - 5 } & Pond water & $24(6 / 25)$ & $28(7 / 25)$ & $50(15 / 30)$ \\
\hline \multirow{2}{*}{ A. hydrophilla } & Diseased fish & $20(2 / 10)$ & $80(8 / 10)$ & $20(2 / 10)$ \\
\cline { 2 - 5 } & Pond water & $100(1 / 1)$ & $100(1 / 1)$ & $0(0 / 1)$ \\
\hline
\end{tabular}

could found that there was no difference of $A$. veronii between diseased fish and water environment, $69.77 \%$ and $89.29 \%$ respectively, but $A$. hydrophila was significantly different $(P<0.05)$. A. hydrophila isolates were significantly more frequent from diseased fish than from water. A similar result was found by Nielsen et al. (2001).

All Aeromonas isolates were screened for three putative virulence genes, aer, hly and alt. The primers are shown in table I. Of 71 strains analyzed, $50(70.43 \%)$ were positive for at least one of the virulence genes examined. Three virulence genes were present in 4/71 (5.63\%) of isolates, among which 3 strains were isolated from diseased fish and the other was from water environment. While 17 (23.94\%) isolates contained two virulence genes, among which 10 were isolated from diseased fish including 5 A. veronii, 4 A. hydrophila and 1 A. salmonicida, and 7 were isolated from water environment including $6 \mathrm{~A}$. veronii and $4 \mathrm{~A}$. hydrophila. The number of Aeromonas isolates containing one virulent gene was the highest. 31(43.66\%) isolates, and included 18 from diseased fish and 13 from water environment.

The positive rate of virulence gene of $A$. veronii and A. hydrophila was compared between isolates from diseased fish and water environment (table III). In A. veronii, $h l y$ was present in nearly half of the strains from diseased fish while alt was present in half of the isolates from water environment. In A. hydrophila, hly was positive in most of the isolates not only diseased fish but also water environment. The positive rate hly was highest among three virulence genes. Several recent studies reported the involved virulence factors in fish infections (Boyd et al., 2008; Dacanay et al., 2010; Li et al., 2011). Janda and Abbott (2010) found that only a small subset of strains containing genes for potential virulence factors seems to cause infection. It is not clear whether there is a virulent subset of Aeromonas species prevalent in clinical isolates with the ability to cause freshwater fish infections.

Our results showed that the species distribution in Aeromonas isolates from diseased fish and water environment in Jiangsu Province of China was similar without significant differences. They indicated that Aeromonas species in aquatic environments are varied and have considerable virulence potential.

\section{Acknowledgements}

This research work was kindly supported by the earmarked fund for National Nonprofit Institute Research Grant of Freshwater Fisheries Research Center, CAFS (2009JBFB17) and Modern Agroindustry Technology Research System (CARS-46).

\section{Literature}

Aberoum A. and H. Jooyandeh. 2010. A review on occurrence and characterization of the Aeromonas species from marine fishes. World J. Fish Mar. Sci. 2: 519-523.

Boyd J.M., A. Dacanay, L.C. Knickle, A. Touhami, L.L. Brown, M.H. Jericho, S.C. Johnson and M. Reith. 2008. Contribution of type IV pili to the virulence of Aeromonas salmonicida subsp. salmonicida in Atlantic salmon (Salmo salar L.). Infect. Immun. 76: 1445-1455.

Demarta A., M. Küpfer, P. Riegel, C. Harf-Monteil, M. Tonolla, R. Peduzzi, A. Monera, M.J. Saavedra and A. Martínez-Murcia. 2008. Aeromonas tecta sp. nov., isolated from clinical and environmental sources. Syst. Appl. Microbiol. 31: 278-286.

Castro-Escarpullia G., M.J. Figueras, G. Aguilera-Arreolaa, L. Solerb, E. Fernández-Rendóna, G.O. Aparicioa, J. Guarrob and M.R. Chacónb. 2003. Characterization of Aeromonas spp. Isolated from frozen fish intended for human consumption in Mexico. Int. J. Food Microbiol. 84: 41-49.

Chacon M.R., M.J. Figueras, G. Castro-Escarpulli, L. Soler and J. Guarro. 2003. Distribution of virulence genes in clinical and environmental isolates of Aeromonas spp. Antonie Van Leeuwenhoek 84: 269-278.

Cristi L., A. Galindo and K. Chopra. 2007. Aeromonas and Plesiomonas species, pp. 381-400. In: M.P. Doyle and L.R. Beuchat (eds.), Food microbiology fundamentals and frontiers. 3rd ed. ASM Press, Washington, DC.

Dacanay A., J.M. Boyd, M.D. Fast, L.C. Knickle and M.E. Reith. 2010. Aeromonas salmonicida type I pilus system contributes to host colonization but not invasion. Dis. Aquat. Organ. 88: 199-206.

Figueras M.J. 2005. Clinical relevance of Aeromonas sM503. Rev. Med. Microbiol. 16: 145-153.

Harf-Monteil C., A. Le Fle'che, P. Riegel, G. Pre'vost, D. Bermond, P. Grimont and H. Monteil. 2004. Aeromonas simiae sp. nov., isolated from monkey faeces. Int. J. Syst. Evol. Microbiol. 54: 481-485. Hu M., N. Wang, Z.H. Pan, C.P. Lu and Y.J. Liu. 2012. Identity and virulence properties of Aeromonas isolates from diseased fish, healthy controls and water environment in China. Letters in Applied Microbiology 55: 224-233.

Hugh R. and E. Leifson. 1953. The taxonomic significance of fermentative versus oxidative metabolism of carbohydrates by various Gram negative bacteria. J. Bacteriol. 66: 24-26.

Janda J.M. and S.L. Abbott. 2010. The genus Aeromonas: taxonomy, pathogenicity, and infection. Clin. Microbiol. Rev. 23: 35-73. 
Kasai H., T. Ezaki and S. Harayama. 2000. Differentiation of phylogenetically related slowly growing Mycobacteria by their $\operatorname{gyr} B$ sequences. J. Clin. Micobiol. 38: 301-308.

Kozinska A. 2007. Dominant pathogenic species of mesophilic aeromonads isolated from diseased and healthy fish cultured in Poland. J. Fish Dis. 30: 293-301.

Li J., X.D. Ni, Y.J. Liu and C.P. Lu. 2011. Detection of three virulence genes alt, ahp and aerA in Aeromonas hydrophila and their relationship with actual virulence to zebrafish. J. Appl. Microbiol. 110: 823-830.

Marchandin H., C. Teyssier, M. Simeon De Buochberg, J.C. Carriere and E. Jumas-Bilak. 2003. Intra-chromosomal heterogeneity between the four 16S rRNA gene copies in the genus Veillonella: implications for phylogeny and taxonomy. Microbiology 149: 1493-1501. Martinez-Murcia A.J., M.J. Saavedra, V.R. Mota, T. Maier, E. Stackebrandt and S. Cousin. 2008. Aeromonas aquariorum sp. nov., isolated from aquaria of ornamental fish. Int. J. Syst. Evol. Microbiol. 58: 1169-1175.

Martin-Carnahan A. and S.W. Joseph. 2005. Order XII. Aeromonadales ord. nov. pp. 556-578. In: D.J. Brenner, N.R. Krieg, J.T. Staley and G.M. Garrity (eds.), Bergey's second ed., vol. 2, PartB, Springer, New York.

Minana Galbis D., M. Farfan, M. Carme Fuste and J.G. Loren. 2004. Aeromonas molluscorum sp. nov., isolated from bivalve molluscs. Int. J. Syst. Evol. Microbiol. 57: 582-587.

Minana-Galbis D., M. Farfan, M.C. Fuste and J.G. Loren. 2007. Aeromonas bivalvium sp. nov., isolated from bivalve molluscs. Int. J. Syst. Evol. Microbiol. 57: 582-587.

Nam J.Y. and K. Joh. 2007. Rapid detection of virulence factors of Aeromonas isolated from a trout farm by hexaplex PCR. J Microbiol. 45: 297-304.

Nawaz Mohamed, A. Khan Saeed, A. Khan Ashraf, Sung Kidon, Tran Quynhtien, Kerdahi Khalil and R. Steele. 2010. Detection and characterization of virulence genes and integrons in Aeromonas veronii isolated from catfish. Food Microbiol. 27: 327-331.

Nielsen M.E., L. Hoi, A.S. Schmidt, D. Qian, T. Shimada, J.Y. Shen and J.L. Larsen. 2001. Is Aeromonas hydrophila the dominant motile Aeromonas species that causes disease outbreaks in aquaculture production in the Zhejiang Province of China. Dis. Aquat Organ. 46: 23-29.
Ottaviani D., Parlani Chiara, Citterio Barbara, Masini Laura, Leoni Francesca, Canonico Cristina, Sabatini Luigia, Bruscolini Francesca and A. Pianetti. 2011. Putative virulence properties of Aeromonas strains isolated from food, environmental and clinical sources in Italy: a comparative study. Int. J. Food. Microbiol. 144: 538-545.

Parker J.L. and J.G. Shaw. 2011. Aeromonas spp. clinical microbiology and disease. J. Infect. 62: 109-118.

Pidiyar V., A. Kaznowski, N.B. Narayan, M. Patole and Y.S. Schouche. 2002. Aeromonas culicicola sp. nov., from the midgut of Culex quinquefasciatus. Int. J. Syst. Evol. Microbiol. 52: 1723-1728. Saavedra M.J., M.J. Figueras and A.J. Martinez-Murcia. 2006. Updated phylogeny of the genus Aeromonas. Int. J. Syst. Evol. Microbiol. 56: 2481-2487.

Saavedra M.J., S. Guedes-Novais, A. Alves, P. Rema, M. Tacao, A. Correia and A. Martinez-Murcia. 2004. Resistance to $\beta$-lactam antibiotics in Aeromonas hydrophila isolated from rainbow trout (Oncorhynchus mykiss). Int. Microbiol. 7: 207-211.

Sen K. and M. Rodgers. 2004. Distribution of six virulence factors in Aeromonas species isolated from US drinking water utilities: a PCR identification. J Appl Microbiol. 97: 1077-1086.

Sha J., E.V. Kozlova and A.K. Chopra. 2002. Role of various enterotoxins in Aeromonas hydrophila -induced gastroenteritis: generation of enterotoxin gene-deficient mutants and evaluation of their enterotoxin activity. Infect Immun. 70: 1924-1935.

Soler L., M.A. Yanez, M.R. Chacon, M.G. Aguilera-Arreola, V. Catalan, M.J. Figueras and A.J. Martinez-Murcia. 2004. Phylogenetic analysis of the genus Aeromonas based on two housekeeping genes. Int. J. Syst. Evol. Microbiol. 54: 1511-1519.

Vilches S., M. Wilhelms, H.B. Yu, K.Y. Leung, J.M. Tomas and S. Merino. 2008. Aeromonas hydrophila AH-3 AexT is an ADPribosylating toxin secreted through the type III secretion system. Microb. Pathog. 44: 1-12.

Yanez M.A., V. Catalan, D. Apraiz, M.J. Figueras and A.J. Martinez-Murcia. 2003. Phylogenetic analysis of members of the genus Aeromonas based on gyrB gene sequences. Int. J. Syst. Evol. Microbiol. 53: 875-883.

Wuming Yang. 2010. Ph.D. Ecological and Epidemiological Studies of the Genus Aeromonas in Freshwater Ponds (in Chinese). Institute of Hydrobiology, Chinese Academy of Sciences. Wuhan. China. 